\title{
Cold tolerance and trehalose accumulation in overwintering larvae of the codling moth, Cydia pomonella (Lepidoptera: Tortricidae)
}

\author{
Abbas KHANI ${ }^{1}$, SAeId MOHARRAMIPOUR ${ }^{1 *}$ and Mohsen BARZEGAR ${ }^{2}$ \\ ${ }^{1}$ Department of Entomology, College of Agriculture, Tarbiat Modares University, PO Box 14115-336, Tehran, Iran \\ ${ }^{2}$ Department of Food Science and Technology, College of Agriculture, Tarbiat Modares University, Tehran, Iran
}

Key words. Tortricidae, cold hardiness, Cydia pomonella, diapause, overwintering, supercooling point, acclimation, trehalose

\begin{abstract}
Seasonal variations in the supercooling point, survival at low temperatures and sugar content were studied in fieldcollected codling moth larvae. The supercooling point of field-collected larvae decreased significantly from a mean value of $-13.4^{\circ} \mathrm{C}$ in August 2004 (feeding larvae) to $-22.0^{\circ} \mathrm{C}$ in December 2004 (overwintering larvae). Survival at $-20^{\circ} \mathrm{C} / 24 \mathrm{~h}$ was $0 \%$ during early autumn, whereas it increased to approximately $60 \%$ during winter. The survival at low temperature was well correlated with the supercooling point. The supercooling point of the diapause destined larvae decreased from -16.9 to $-19.7^{\circ} \mathrm{C}$ between September and October as the larvae left the food source and spun a cocoon. For early-diapause larvae, exposure to $5^{\circ} \mathrm{C} / 30$ days has an additional effect and decreased the supercooling point from -19.7 to $-21.3^{\circ} \mathrm{C}$. One-month exposure of overwintering larvae to $5^{\circ} \mathrm{C}$ led to a mortality of $23 \%$ in early diapause larvae, while only $4 \%$ of diapause larvae died after acclimation. Overwintering larvae accumulated trehalose during winter. There was approximately a threefold increase in trehalose content between larvae at the onset of diapause $(5.1 \mathrm{mg} / \mathrm{g}$ fresh weight) and larvae in a fully developed diapause $(18.4 \mathrm{mg} / \mathrm{g}$ fresh weight) collected in January. Trehalose content was correlated with supercooling capacity, survival at low temperatures and chilling tolerance, suggesting that trehalose may play some role in the development of cold tolerance in this species.
\end{abstract}

\section{INTRODUCTION}

Cold hardiness and diapause are essential components of winter survival for most insects in temperate zones (Denlinger, 1991). Cold-tolerance strategies of insects have generally been divided into two major categories. Freeze-tolerant species survive the formation of internal ice, while freeze-avoiding insects are unable to survive at temperatures causing ice formation in the body fluids (Sømme, 1999). The large majority of terrestrial arthropods (e.g. codling moth: Siegler, 1946; Neven, 1999) that have been investigated are freeze-avoiding (Block, 1991; Sømme, 1999). In freeze-avoiding species, which survive in a supercooled state, low-molecular weight sugars and polyols including glycerol, sorbitol, mannitol, inositol and trehalose may accumulate as cryoprotective agents (reviewed in Sømme, 1982; Denlinger, 1991; Lee, 1991; Storey \& Storey, 1991).

The codling moth, Cydia pomonella, is a key pest of apple in various regions of Iran (Rajabi et al., 1978; Akrami, 1984; Saeb, 1994). This moth passes the winter as a full-grown diapausing larva within a thick, silken cocoon under loose bark on the trunks of apple trees. The codling moth has successfully followed the spread of apple cultivation and occurs in most apple production areas throughout the world (Barnes, 1991; Dorn et al., 1999) inhabiting various climates, even where winter temperatures sometimes reach as low as $-25^{\circ} \mathrm{C}$ (Newcomer, 1920; Yothers \& Carlson, 1941; Geier, 1963; Sato, 1964; Hagley, 1970; Berankova et al., 1988).
Temperature profoundly affects growth and its underlying processes (Gillooly et al., 2001). Insect activity slows if the temperature is reduced to below developmental thresholds and insects die if exposed to low temperatures for a sufficiently great period (Fields, 1992; Hagstrum \& Flinn, 1994). The effect of temperature on growth, development, activity and thermoregulation behaviour is one of the widely investigated aspects of the eco-physiology of the codling moth (Glenn, 1922; Shel'deshova, 1967; Riedl \& Croft, 1978; Glen \& Brain, 1982; Richardson et al., 1982; Gottwald, 1996; Howell \& Neven, 2000; Howell \& Schmidt, 2002; Sæthre \& Hofsvang, 2002; Raudonis, 2002; Kuhrt et al., 2005, 2006; Bloem et al., 2006). Exposure of codling moth larvae to temperatures below the lower physiological threshold arrests development but is not lethal unless freezing occurs. Moreover, the diapausing stages are not merely capable of withstanding prolonged cooling, but an exposure at low temperature is required to terminate diapause (Neven et al., 2000). So, a seasonal change in temperature is essential for the lifecycle of the codling moth.

Studies on the cold hardiness of this pest have been performed since the early part of this century. Controlling codling moth larvae with low-temperature storage as a quarantine treatment is studied in apples and stone fruits (Newcomer, 1936; Moffitt \& Albano, 1972; Yokoyama \& Miller, 1989; Toba \& Moffitt, 1991; Neven, 1994). Siegler (1946) demonstrated that codling moths were freezing sensitive with whole body supercooling points between -25 and $-30^{\circ} \mathrm{C}$. The lowest temperature tolerated

\footnotetext{
* Corresponding author; e-mail: moharami@modares.ac.ir, moharramipour@yahoo.com
} 
by codling moth was around $-31^{\circ} \mathrm{C}$ (Shel'deshova, 1967). The lower lethal temperature of non-diapausing codling moth larvae was significantly higher than the whole body supercooling points, which indicated chill sensitivity in actively feeding larvae. However, lower lethal temperatures of diapausing larvae were similar to the average whole body supercooling point, which indicated that the diapausing larvae were freezing intolerant (Neven, 1999). Accumulation of glycerol as a cryoprotectant was shown in overwintering codling moth larvae by Minder et al. (1984), but Neven (1999) demonstrated that diapausing larvae (diapause induction condition: $18 \pm 2^{\circ} \mathrm{C}, 8 \mathrm{~L}: 16 \mathrm{D}$ ) did not accumulate appreciable levels of glycerol and trehalose and principally remove exogenous ice nucleators to avoid ice formation. The capacity for polyol accumulation may change seasonally. For example, many species of insects initiate polyol synthesis at low temperatures (Hayakawa \& Chino, 1981; Storey \& Storey, 1983; Nordin et al., 1984). The trigger temperature with the maximal rate of polyol synthesis in insects is typically in the 0 to $5^{\circ} \mathrm{C}$ range (Storey \& Storey, 1988). Additionally a thermoperiod can accelerate this process (Pio \& Baust, 1988; Koštál et al., 2001). However, these trigger temperatures were not applied in research performed by Neven (1999). So, in this study, we used field collected diapausing larvae of the codling moth.

The main purpose of the present study was to integrate the information obtained by simultaneously recording physiological and biochemical aspects of cold hardiness with the microclimate conditions in the overwintering habitat of a wild population of the codling moth. Such integration aims to provide a better understanding of overwintering strategy in its entirety. Field data obtained in this study are used to verify and extend earlier laboratory experiments.

\section{MATERIAL AND METHODS}

\section{Insects}

Actively feeding larvae of $C$. pomonella (third through fifth instars that immediately continue direct development and develop into pupae) were obtained from infested apples in August 2004. Larvae at the onset of diapause and larvae in full diapause were collected from silken cocoons which were formed in cardboard bands placed around the trunks of apple trees (overwintering sites), in Damavand, Iran $\left(35^{\circ} 39^{\prime} \mathrm{N}\right.$, $52^{\circ} 05^{\prime} \mathrm{E}$; alt. $1800 \mathrm{~m}$ ) from September 2004 to March 2005.

\section{Determination of supercooling points}

The supercooling points (SCPs) of individual larva $(n=$ 10-12 larvae from each month) were measured using a thermocouple (NiCr-Ni probe) connected to an automatic temperature recorder, Testo 177-T4 (Testo, Germany), so that the cooling could be recorded at $0.5 \mathrm{~min}$ intervals and the data read using Comsoft 3 software. The specimens were attached to the thermocouple by adhesive tape and placed inside a programmable refrigerated test chamber (Binder GmbH Bergstr., model MK 53 , Germany) the temperature of which was lowered at a rate of $0.5^{\circ} \mathrm{C} / \mathrm{min}$, starting at $20^{\circ} \mathrm{C}$ and ending at $-30^{\circ} \mathrm{C}$. The temperature at which an abrupt temperature increase occurred with the liberation of the latent heat of freezing was taken as the SCP.

\section{Determination of low temperature survival}

Larvae were collected monthly from August to March and transferred ( $n=30$ larvae, 3 replicates of 10 larvae, for each temperature) to a programmable refrigerated test chamber and the temperature lowered at a rate of $0.5^{\circ} \mathrm{C} / \mathrm{min}$, from $20^{\circ} \mathrm{C}$ to the desired treatment temperature $\left(-15,-20\right.$ or $\left.-25^{\circ} \mathrm{C}\right)$. The larvae were held at these temperatures for $24 \mathrm{~h}$ and then slowly $\left(0.5^{\circ} \mathrm{C} / \mathrm{min}\right)$ heated to $25^{\circ} \mathrm{C}$ and held at that temperature for 24 h. Live and dead larvae were counted and the larvae showing no movement were judged to be dead.

\section{Long-term exposure to low temperature}

Chill tolerance was evaluated by transferring overwintering larvae from outdoors to $5^{\circ} \mathrm{C}$ for 30 days in the dark. The larvae were collected in early October (onset of diapause), late November (diapause) and mid March (late diapause). The survival at $5^{\circ} \mathrm{C} / 30$ days was determined and the supercooling point was measured in randomly selected individuals.

\section{Measurement of sugar alcohols content}

The supercooling point of the larvae was determined before analysis of sugar alcohols. Whole body extracts were obtained from individual larvae $(n=4-5$ larvae from each month). The extracts $\left(80 \%\right.$ ethanol) were evaporated at $40^{\circ} \mathrm{C}$ in a vacuum drying oven (Vision Scientific Co., model VS-1202V5, Korea) and then resuspended in $250 \mu \mathrm{l}$ of HPLC grade water. Just before the sample injection, the samples were further cleaned by passing through a $0.45 \mu \mathrm{m}$ syringe filter. Sugars and polyols were analyzed by high-performance liquid chromatography (Waters, Milford, MA, USA) using a carbohydrate column with $4 \mu \mathrm{m}$ particle size $(250 \mathrm{~mm} \times 4.6 \mathrm{~mm}$, I.D., Waters, Ireland $)$. The eluent was acetonitrile-water $(70: 30)$ and elution speed was $1 \mathrm{ml} \mathrm{min}-1$. Separation was achieved at $40 \pm 1^{\circ} \mathrm{C}$. All aqueous solutions were degassed by helium gas. Aliquots of whole body extracts $(50 \mu \mathrm{l})$ were run along with standards of glucose, glycerol and trehalose from 250 to $5000 \mathrm{ppm}$.

\section{Weather data}

Air temperature data were obtained from the Hamand-Absard Agrometeorological Station, Data Processing Center of Iranian Meteorological Organization (IMO). The station was located 1 $\mathrm{km}$ from the sampling site.

\section{Statistical analysis}

Statistical analysis of the sugar content data was performed by one-way analysis of variance (ANOVA) with a post-hoc Tukey test using SPSS version 13.00 for Windows. Normality was tested using a Kolmogorov-Smirnov test. A non-parametric test (Mann-Whitney U and Kruskal-Wallis test) was used to test for differences in the supercooling point data. For investigating a supposed linear relationship between two variables, a Pearson correlation test was used. The results were expressed as mean \pm SE, and considered significantly different at $P<0.05$.

\section{RESULTS}

The average ambient temperature in Damavand, Iran was $23.0^{\circ} \mathrm{C}$ in August, declining to $18.6^{\circ} \mathrm{C}$ in September, $15.1^{\circ} \mathrm{C}$ in October, $5.2^{\circ} \mathrm{C}$ in November and close to $0.4^{\circ} \mathrm{C}$ in January, before increasing to $3.4^{\circ} \mathrm{C}$ in March. The minimum monthly temperature was below $0^{\circ} \mathrm{C}$ from November to the end of March, with the lowest in January $\left(-4.0^{\circ} \mathrm{C}\right)$ (Fig. 1).

\section{Supercooling points}

The supercooling points of feeding non-diapausing larvae varied between -8.2 to $-16.9^{\circ} \mathrm{C}($ mean $=-12.80 \pm$ 


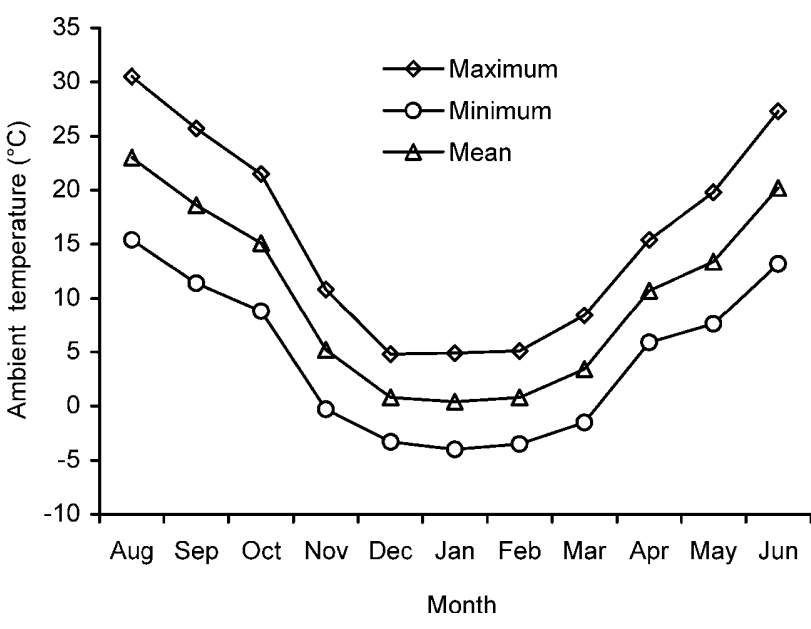

Fig. 1. Seasonal changes in average, minimum and maximum ambient temperatures in Damavand (Hamand-Absard) between August, 2004 and June, 2005.

1.0), regardless of instar. Whole body supercooling points of overwintering larvae changed significantly from September through March (Kruskal-Wallis test, $\mathrm{P}<0.01$ ). Diapause destined larvae left the fruit and spun a thick, silken cocoon under loose bark on the trunks of apple trees in early September. The larvae which were collected from infested fruits at this time had a mean SCP of -16.9 $\pm 1.1^{\circ} \mathrm{C}$ with a range from -14.4 to $-19.8^{\circ} \mathrm{C}$, while early diapausing larvae which were collected from silken cocoons (overwintering sites) in early October, had a mean SCP of $-19.7 \pm 0.5^{\circ} \mathrm{C}$. The SCP decreased towards early winter with a minimum of $-22.03 \pm 0.9^{\circ} \mathrm{C}$ in December, then the SCP increased from January onwards and had a mean value of $-19.4 \pm 0.4^{\circ} \mathrm{C}$ in March (Table 1). Supercooling points of overwintering larvae were significantly lower than those of feeding non-diapausing larvae (Mann-Whitney U test, $\mathrm{P}<0.05$, Table 1).

\section{Low temperature survival}

The least cold hardiness was found in feeding nondiapausing individuals with a survival of less than $10 \%$ following exposure at $-15^{\circ} \mathrm{C} / 24 \mathrm{~h}$. The cold hardiness of

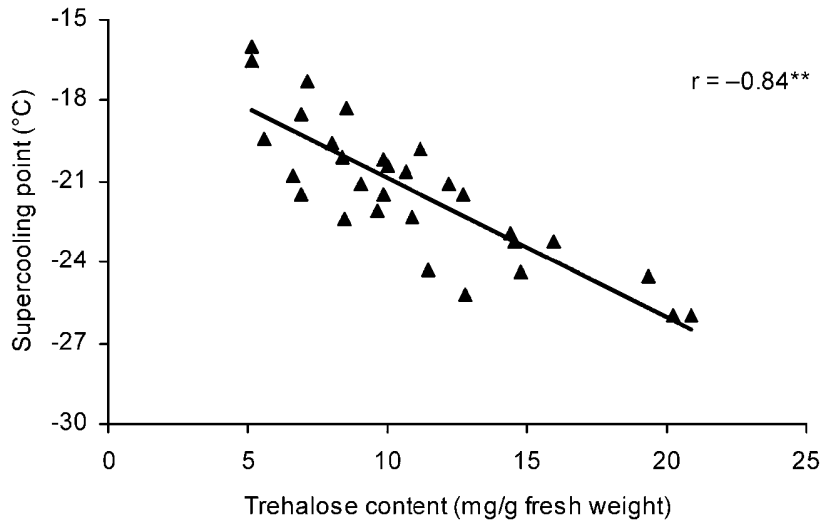

Fig. 2. Relationship between the supercooling capacity and trehalose content in overwintering larvae of $C$. pomonella during 2004-2005. Pearson correlation test was used for investigating a linear relationship between the two variables. The correlation was significant at $P<0.01$.

diapause destined larvae was higher than that of nondiapausing larvae and survival at $-15^{\circ} \mathrm{C} / 24 \mathrm{~h}$ increased to $45 \%$ for individuals collected in September (Table1). The cold hardiness increased gradually during autumn and winter. This increase was expressed as greater capacity to survive at $-15^{\circ} \mathrm{C} / 24 \mathrm{~h}(100 \%)$ and $-20^{\circ} \mathrm{C} / 24 \mathrm{~h}(60 \%)$ but not at $-25^{\circ} \mathrm{C} / 24 \mathrm{~h}(0 \%)$ (Table1). The cold hardiness of hibernating larvae decreased again in March with the onset of spring.

\section{Low-molecular weight carbohydrate contents}

The major sugars in C. pomonella larvae were found to be trehalose and glucose. Glycerol was detected in low amounts (0.9-1.8 mg/g fresh weight). Sugar content (trehalose, glucose and glycerol) in non-diapausing larvae was lower than that of diapausing larvae (Table 1).

Trehalose content was about $5.1 \mathrm{mg} / \mathrm{g}$ fresh weight in September. Trehalose levels changed significantly between October and January $\left(F_{3,18}=24.3, P<0.0001\right)$, ranging from $6.9 \mathrm{mg} / \mathrm{g}$ fresh weight in October to a peak of $18.4 \mathrm{mg} / \mathrm{g}$ fresh weight in January and to $10.4 \mathrm{mg} / \mathrm{g}$ fresh weight in March. There was a significant negative

TABLE 1. Relationship among low temperature survival rate, supercooling point and low molecular weight sugar content of diapausing (September-March) and non-diapausing (August) larvae of the codling moth in 2004-2005.

\begin{tabular}{|c|c|c|c|c|c|c|}
\hline \multirow{2}{*}{ Date } & \multirow{2}{*}{$\mathrm{SCPs}\left({ }^{\circ} \mathrm{C}\right)^{1,2}$} & \multicolumn{2}{|c|}{ Survival rate $(\%)^{1}$} & \multicolumn{3}{|c|}{ Sugar content (mg/g fresh weight $)^{1,3}$} \\
\hline & & $-15^{\circ} \mathrm{C} / 24 \mathrm{~h}$ & $-20^{\circ} \mathrm{C} / 24 \mathrm{~h}$ & Glycerol & Glucose & Trehalose \\
\hline Aug & $-12.8 \pm 1.0 \mathrm{a}$ & $8.0 \pm 6.7$ & $0.0 \pm 0.0$ & $0.9 \pm 0.3$ & $2.9 \pm 0.2 \mathrm{~b}$ & $4.8 \pm 1.5 \mathrm{~d}$ \\
\hline Sep & $-16.9 \pm 1.1 b$ & $45.0 \pm 4.0$ & $0.0 \pm 0.0$ & $1.7 \pm 0.2$ & $3.7 \pm 0.2 \mathrm{~b}$ & $5.1 \pm 0.1 \mathrm{~d}$ \\
\hline Oct & $-19.7 \pm 0.5 \mathrm{bc}$ & $93.0 \pm 3.3$ & $6.7 \pm 3.3$ & $1.8 \pm 0.2$ & $4.4 \pm 0.3 \mathrm{ab}$ & $6.9 \pm 0.2 \mathrm{~cd}$ \\
\hline Nov & $-21.8 \pm 0.2 \mathrm{c}$ & $100.0 \pm 0.0$ & $40.0 \pm 4.2$ & $1.5 \pm 0.2$ & $5.8 \pm 0.9 \mathrm{ab}$ & $7.4 \pm 1.0 \mathrm{bcd}$ \\
\hline Dec & $-22.0 \pm 0.9 \mathrm{c}$ & $100.0 \pm 0.0$ & $63.3 \pm 6.3$ & $1.3 \pm 0.1$ & $4.0 \pm 0.2 \mathrm{ab}$ & $13.3 \pm 2.1 \mathrm{abc}$ \\
\hline Jan & $-21.3 \pm 1.1 \mathrm{c}$ & $100.0 \pm 0.0$ & $56.3 \pm 4.2$ & $1.5 \pm 0.2$ & $5.9 \pm 1.6 \mathrm{ab}$ & $18.4 \pm 0.8 \mathrm{a}$ \\
\hline Feb & $-18.9 \pm 1.4 b c$ & $100.0 \pm 0.0$ & $60.0 \pm 2.5$ & $1.3 \pm 0.2$ & $4.2 \pm 0.3 \mathrm{ab}$ & $13.7 \pm 1.5 \mathrm{ab}$ \\
\hline Mar & $-18.8 \pm 0.7 b$ & $93.3 \pm 3.3$ & $46.7 \pm 3.3$ & $1.5 \pm 0.03$ & $7.9 \pm 1.0 \mathrm{a}$ & $10.4 \pm 1.6 \mathrm{bcd}$ \\
\hline
\end{tabular}

${ }^{1}$ Mean \pm SE; ${ }^{2}$ Values with the different letters in the supercooling point column are significantly different $(p<0.05)$ (Mann-Whitney $\mathrm{U}$ test) ${ }^{3}$ Values with the different letters in the sugar content columns are significantly different $(p<0.05)$ (Tukey post-hoc test after analysis of variance). Seasonal changes of glycerol were not significant. 
TABLE 2. Effects of cold acclimation $\left(30\right.$ days at $\left.5^{\circ} \mathrm{C}\right)$ on the supercooling point and survival of overwintering larvae of codling moth.

\begin{tabular}{ccccc}
\hline Collection date & Treatment & SCP $\left({ }^{\circ} \mathrm{C}\right)$ Mean \pm SE & Range $\left({ }^{\circ} \mathrm{C}\right)($ Min., Max. $)$ & Mortality $(\%)$ \\
\hline \multirow{2}{*}{ 6 Oct. 2004} & NAC & $-19.75 \pm 0.51^{2} \mathrm{a}$ & $-22.0,-17.4(10)^{3}$ & $23.3(75.0)^{3}$ \\
& AC & $-21.30 \pm 0.43 \mathrm{~b}$ & $-24.8,-19.9(11)$ & $<4.0(50.0)$ \\
26 Nov. 2004 & NAC & $-21.10 \pm 0.48 \mathrm{a}$ & $-25.9,-18.9(16)$ & $13.6(100)$ \\
& AC & $-21.77 \pm 0.87 \mathrm{a}$ & $-26.6,-13.9(17)$ & $-21.5,-17.9(12)$ \\
\hline
\end{tabular}

${ }^{1} \mathrm{NAC}$ - non-acclimated, $\mathrm{AC}-$ acclimated $\left(30\right.$ days at $\left.5^{\circ} \mathrm{C}\right) ;{ }^{2}$ Same letters indicate that the mean $\pm \mathrm{SE}$ are not significantly different at the $5 \%$ level (independent $t$-student test); ${ }^{3}$ Number of observations is indicated in parentheses.

correlation between supercooling point and trehalose content $(r=-0.838, n=30 ; P<0.0001$, Fig. 2$)$ in the overwintering larvae.. The increase in cold hardiness was associated with an increase in the trehalose content of the overwintering larvae (Table 1).

Glucose content varied between 3.7 and $5.8 \mathrm{mg} / \mathrm{g}$ fresh weight during autumn and winter, but this was not significant $(P>0.05)$. Glucose content increased significantly to $8 \mathrm{mg} / \mathrm{g}$ fresh weight in March with the onset of spring.

\section{Long-term exposure to low temperature}

One-month exposure to $5^{\circ} \mathrm{C}$ led to a $23 \%$ mortality of larvae in early October (Table 2). Overwintering larvae gradually became cold hardy in autumn and a high level of chill tolerance with less than $5 \%$ mortality at $5^{\circ} \mathrm{C} / 30$ days was observed in late November. Chill tolerance then decreased in March and about 14\% of cold acclimated larvae died during this period (Table 2).

Long-term acclimation $\left(5^{\circ} \mathrm{C} / 30\right.$ days $)$ of early diapausing larvae collected in October led to a significant decrease of supercooling points from $-19.72 \pm 0.51$ to $-21.3 \pm 0.435^{\circ} \mathrm{C}(t=2.379$, d.f. $=19, P<0.05$, Table 2$)$. Supercooling points declined marginally in cold acclimated larvae collected in November and March but this decrease was not significant $(t=0.664$, d.f. $=31$ and $t=$ 0.459 , d.f. $=34$ respectively; $P>0.05$, Table 2 ). The individual variation in the SCP values increased considerably in cold acclimated larvae collected in November and March (Table 2, Fig. 3).

\section{DISCUSSION}

In this paper, we describe some of the physiological and biochemical features of cold hardiness in a wild population of $C$. pomonella with special attention to overwintering. Larvae were collected regularly (approximately each month) for one year. Changes in supercooling capacity, cold hardiness and content of a potential cryoprotectant (trehalose) were related to the seasonal development of diapause.

Gradually decreasing temperatures in autumn resulted in a continuing reduction of the SCP and enhancement of cold hardiness that was demonstrated by increased low temperature survival. Variation in the parameters related to cold hardiness (SCPs, low temperature survival, trehalose content) during the cool winter season (October through February) shows that overwintering larvae of the
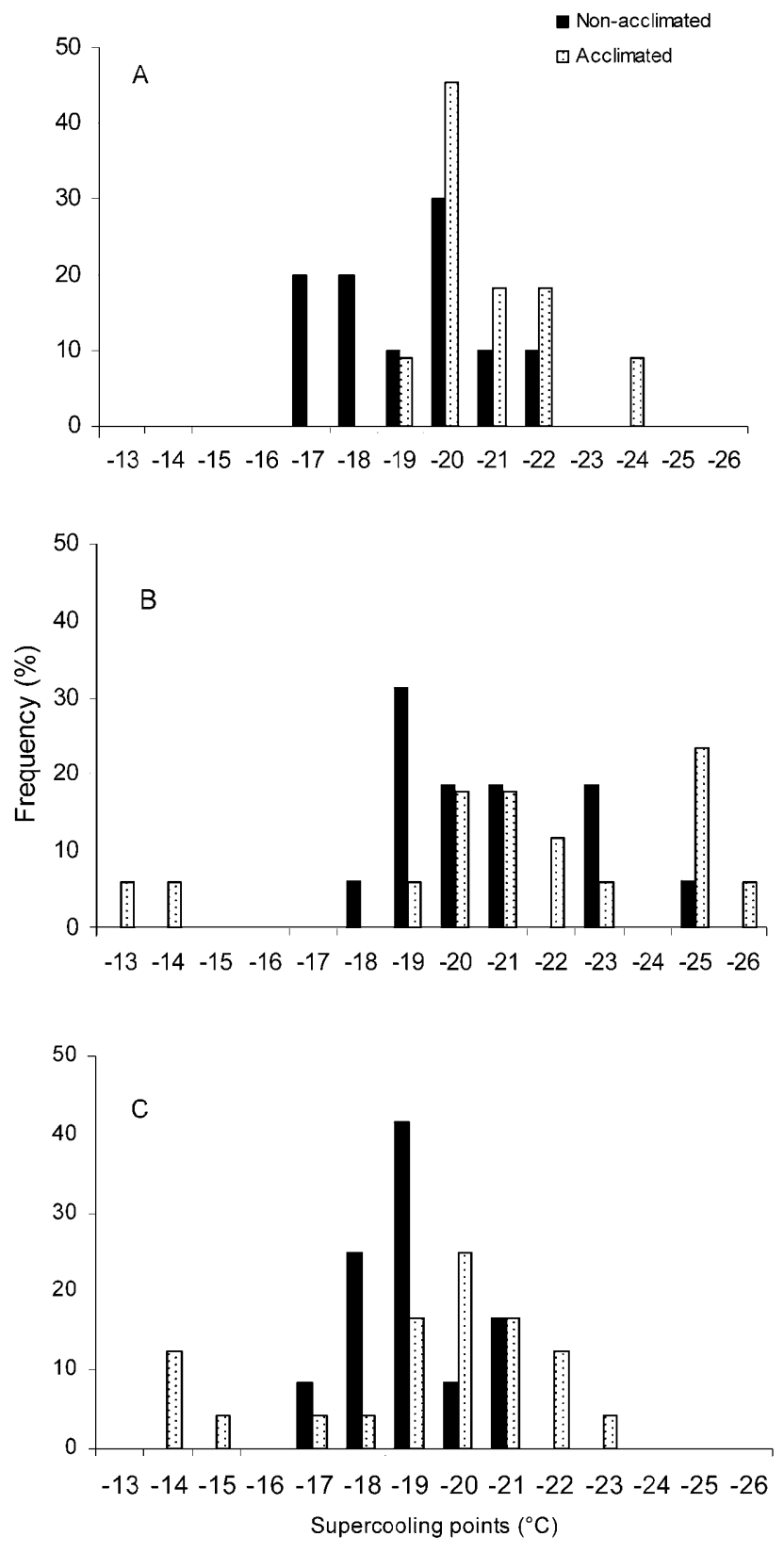

Fig. 3. Frequency distribution of supercooling points of diapausing larvae of C. pomonella collected in early October (A), late November (B) and mid March (C) after or before acclimation to $5^{\circ} \mathrm{C} / 30$ days. 
codling moth could adjust their cold hardiness to the environmental conditions.

Survival rates after 1-day-long exposures to $-15^{\circ} \mathrm{C}$ and $-20^{\circ} \mathrm{C}$ corresponded well to the SCP values and allowed the use of the SCP value as a good and rapid estimate of the cold hardiness. This tight relationship between SCP and lower lethal temperature was recognized earlier in laboratory experiments (Neven, 1999).

The codling moth was found to be a freezing intolerant insect since the overwintering larvae could not tolerate temperatures lower than the supercooling point (e.g $-25^{\circ} \mathrm{C}$ used in this study). Death after supercooling point determination has been reported in other freezing intolerant insects (Coulson \& Bale, 1996; Needham et al., 1996; Jones \& Kunz, 1997).

Minder et al. (1984) reported that the increase in supercooling capacity coincided with the onset of diapause. In addition, Neven (1999) reported that the lower lethal temperature of diapause destined codling moth larvae (laboratory samples) decreased considerably with diapause development. Similarly, our field data showed that the overwintering larvae had a relatively higher SCP and accordingly lower cold hardiness during non-diapausing and early diapause states. However, during the development of diapause the SCP gradually decreased and both cold hardiness and chill tolerance increased accordingly in agreement with earlier laboratory experiments (Neven, 1999). One day exposure to $-20^{\circ} \mathrm{C}$ was successfully tolerated by diapause larvae (40-60\% mortality), whilst this treatment caused $100 \%$ mortality in feeding non-diapause larvae.

Parallel to survival at $-20^{\circ} \mathrm{C} / 24 \mathrm{~h}$, the highest chill tolerance $\left(5^{\circ} \mathrm{C} / 30\right.$ days $)$ with less than $5 \%$ mortality was observed after the larvae entered diapause during autumn (Table 2). Cydia pomonella larvae were categorized as being chill tolerant according to Bale's (1993) classification. As with our results, it has been reported by previous authors that codling moth larvae survived in the stored apples for up to 3 months at $0-4^{\circ} \mathrm{C}$ during post harvest conditions (Moffitt \& Albano, 1972; Toba \& Moffitt, 1991).

Cold acclimation resulted in a decrease in the mean SCP (about $1.5^{\circ} \mathrm{C}$ ) of early diapausing larvae collected in early October, while cold acclimated larvae in late November and March showed only a slight decrease in the supercooling point (about $0.5^{\circ} \mathrm{C}$ ). In addition, the individual variation in the SCP value increased considerably after cold acclimation for diapausing larvae collected in November and March, but not for diapausing larvae collected in October (Fig. 3). These differences may be due to differences in diapause intensity in the various stages of diapause.

Winter accumulation of low molecular weight sugars and/or polyols has been well documented in many overwintering insects from polar and temperate regions (for a review see Sømme, 1982). Although accumulation of glycerol as a cryoprotectant was shown in overwintering larvae of the codling moth by Minder et al. (1984), similar information was lacking for $C$. pomonella in a study by Neven (1999). Neven (1999) did not find a significant difference in the whole body levels of trehalose or glycerol between diapause induced and non-diapausing larvae of codling moth and demonstrated that diapausing codling moth larvae supercool to avoid lethal freezing by removal of ice nucleators from the gut and body without an appreciable increase in antifreeze agents such as polyols. However, our field data showed that the overwintering codling moth larvae accumulated high levels of trehalose and that there was a significant relationship between trehalose content and both the decrease in supercooling point and the development of cold hardiness in this species. We found that trehalose was the dominant sugar accumulated in the overwintering $C$. pomonella larvae with a maximum concentration of ca. $2 \%$ fresh weight. Analysis of sugars in the whole body showed an almost threefold difference in trehalose content between early diapausing larvae $(5 \mathrm{mg} / \mathrm{g}$ fresh weight) and diapause larvae $(18 \mathrm{mg} / \mathrm{g}$ fresh weight) collected in January. Although the concentrations of trehalose were too low to bring about any considerable effect through depression of supercooling points by colligative action (Zachariassen, 1985; Zachariassen et al., 2004), we found temporal correlation between the increase of trehalose and the decrease of SCP/increase of cold hardiness. This relationship suggests that trehalose plays an important role in the overwintering strategy of the codling moth. Trehalose, the major insect blood sugar, has previously been considered a cryoprotectant in some insect species (Storey \& Storey, 1991; Rojas et al., 1994; Koštál \& Šimek, 1995, 1996; Goto et al., 2001; Koštál et al., 2001; Nomura \& Ishikawa, 2001), but not in others (Naeemullah et al., 1999; Miyazaki et al., 2006). Despite widespread interest in cryoprotection, the mechanism by which trehalose confers cryoprotection is unknown. Trehalose may operate as a cryoprotectant against cold injury by stabilizing proteins and/or membranes at low temperatures (Rojas et al., 1991, 1994; Ring \& Danks, 1998). It also may reduce the melting point, and hence the freezing point, by osmotic effects (Danks, 2006). It is noteworthy that exogenous trehalose helps protect a variety of organisms against freezing (Leslie et al., 1995; Pellerin-Mendes et al., 1997; Diniz-Mendes et al., 1999; Zhou et al., 2006). This ability of trehalose to protect against freezing led us to hypothesize that trehalose accumulation in microorganisms may also serve as a natural adaptation to decreased temperatures that helps prevent loss of viability in the cold or upon freezing (Rudolph \& Goins, 1991; Kandror et al., 2002).

The loss of cryoprotectants in spring is linked to the termination of diapause in many species (Tsumuki, 1990). The decrease in trehalose content and increase in glucose content in diapausing larvae in March may indicate diapause termination.

In this study, we have demonstrated at least in part the physiological adaptations for winter survival of C. pomonella larvae. Diapause induced larvae appear in early September. After moving to their overwintering sites they cease feeding and may remove ice nucleators from the gut 
which enables them to increase their supercooling capacity in early autumn (October). Larvae at this time have the ability to survive an exposure to subzero temperatures $\left(-15^{\circ} \mathrm{C} / 24 \mathrm{~h}\right)$. Afterward the low temperatures that are experienced by larvae as winter develops are apparently the trigger for supplemental synthesis of trehalose as a cryoprotectant that is responsible for the decreases in supercooling point and increases in survival at low temperatures. So far, no information regarding the cryoprotective effect of trehalose in the codling moth has been reported. A common proof that this substance acts as cryoprotectant in codling moths is that there is a positive correlation between cold tolerance and trehalose content. A more rigorous proof seems to be necessary to demonstrate a causative relationship between the elevated trehalose concentration and the rise in cold tolerance. Physiological approaches to change trehalose levels in vivo would be useful to examine this relationship (Sømme, 1968; Holman et al., 1990; Kono et al., 1994).

\section{REFERENCES}

Aкrami F. 1984: Diapause of codling moth in east Azerbaijan. Appl. Entomol. Phytopathol. 52: 1-6.

BALE J.S. 1993: Classes of insect cold hardiness. Funct. Ecol. 7: 751-753.

BARNES M.M. 1991: Tortricids in pome and stone fruits. In Van Der Geest L.P.S. \& Evenhuis H.H. (eds): Tortricid Pests, Their Biology, Natural Enemies and Control. Elsevier, Amsterdam, pp. 313-327.

Beranková J., Barták M. \& Kocourek F. 1988: Variability in spring emergence of the overwintering generation of codling moth Cydia pomonella (L.). Acta Entomol. Bohemoslov. 85: 274-282.

BLock W. 1991: To freeze or not to freeze? Invertebrate survival of sub-zero temperatures. Funct. Ecol. 5: 284-290.

Bloem S., Carpenter J.E. \& Dorn S. 2006: Mobility of massreared diapaused and nondiapaused Cydia pomonella (Lepidoptera: Tortricidae): Effect of different constant temperatures and lengths of cold storage. J. Econ. Entomol. 99: 707-713.

Coulson S.J. \& BaLE J.S. 1996: Supercooling and survival of the beech leaf mining weevil Rhynchaenus fagi L. (Coleoptera: Curculionidae). J. Insect Physiol. 42: 617-623.

DANKS H.V. 2006: Insect adaptations to cold and changing environments. Can. Entomol. 138: 1-23.

Denlinger D.L. 1991: Relationship between cold hardiness and diapause. In Lee R.E. \& Denlinger D.L. (eds): Insects at Low Temperature. Chapman \& Hall, New York, pp. 174-198.

Diniz-Mendes L., Bernardes E., De Araujo P.S., Panek A.D. \& PaschoAlin V.M. 1999: Preservation of frozen yeast cells by trehalose. Biotechnol. Bioeng. 65: 572-578.

Dorn S., Schumacher P., Abivardi C. \& Meyhöfer R. 1999: Global and regional pest insects and their antagonists in orchards: spatial dynamics. Agric. Ecosyst. Environ. 73: 111-118.

FIELDS P.G. 1992: The control of stored-product insects and mites with extreme temperatures. J. Stored Prod. Res. 28: 89-118.

GEIER P.W. 1963: Wintering and spring emergence of codling moth, Cydia pomonella (L.) (Lepidoptera: Tortricidae), in south-eastern Australia. Aust. J. Zool. 11: 431-435.
Gillooly J.F., Brown J.H., West G.B., Savage V.M. \& Charnov E.L. 2001: Effects of size and temperature on metabolic rate. Science 293: 2248-2251.

Glen D.M. \& Brain P. 1982: Pheromone-trap catch in relation to the phenology of codling moth (Cydia pomonella). Ann. Appl. Biol. 101: 429-440.

GLENN P.A. 1922: Relation of temperature to development of the codling-moth. J. Econ. Entomol. 15: 193-198.

Goto M., Li Y.P., Kayaba S., Outani S. \& Suzuki K. 2001: Cold hardiness in summer and winter diapause and postdiapause pupae of the cabbage armyworm, Mamestra brassicae L. under temperature acclimation. J. Insect Physiol. 47: 709-714.

GotTwaLd R. 1996: Prognose der phänologie wichtiger schadorganismen im apfelbau mit hilfe von temperatursummen. Ges. Pflanzen 48: 140-146.

Hagley E.A.C. 1970: The distribution and survival of overwintering codling moth larvae in southern Ontario. Proc. Entomol. Soc. Ont. 100: 40-47.

Hagstrum D.W. \& Flinn P.W. 1994: Survival of Rhyzopertha dominica (Coleoptera: Bostrichidae) in stored wheat under fall and winter temperature conditions. Environ. Entomol. 23: 391-395.

Hayakawa Y. \& Chino H. 1981: Temperature-dependent interconversion between glycogen and trehalose in diapausing pupae of Philosamia cynthia ricini and pryeri. Insect Biochem. 11: 43-47.

Holman G.M., NAChMAN R.J. \& Wright M.S. 1990: Insect neuropeptides. Annu. Rev. Entomol. 35: 201-217.

Howell J.F. \& Neven L.G. 2000: Physiological development time and zero development temperature of the codling moth (Lepidoptera: Tortricidae). Environ. Entomol. 29: 766-772.

Howell J.F. \& SCHмIDT R.S. 2002: Codling moth (Lepidoptera: Tortricidae): Development at constant and at orchard temperatures. J. Agri. Urban Entomol. 19: 15-23.

JoNES S.R. \& KUNZ S.E. 1997: Importance of supercooling points in the overwintering of the horn fly and stable fly (Diptera: Muscidae). J. Medical Entomol. 34: 426-429.

Kandror O., Deleon A. \& Goldberg A.L. 2002: Trehalose synthesis is induced upon exposure of Escherichia coli to cold and is essential for viability at low temperatures. Proc. Natl. Acad. Sci. USA 99: 9727-9732.

Kono Y., Takahasi M., Matsushita K., Nishina M., Kameda Y. \& HorI E. 1994: Inhibition of flight in Periplaneta americana (Linn.) by a trehalase inhibitor, validoxylamine A. J. Insect Physiol. 40: 455-461.

KošŤÁL V. \& ŠimeK P. 1995: Dynamics of cold hardiness, supercooling and cryoprotectants in diapausing and non-diapausing pupae of the cabbage root fly, Delia radicum L. J. Insect Physiol. 41: 627-634.

KošŤÁL V. \& ŠIMEK P. 1996: Biochemistry and physiology of aestivohibernation in the adult apple blossom weevil Anthonomus pomorum (Coleoptera: Curculionidae). J. Insect Physiol. 42: 727-733.

KošŤÁl V., ŠLACHTA M. \& ŠIMEK P. 2001: Cryoprotective role of polyols independent of the increase in supercooling capacity in diapausing adults of Pyrrhocoris apterus (Heteroptera: Insecta). Comp. Biochem. Physiol. (B) 130: 365-374.

Kuhrt U., SAmietz J. \& Dorn S. 2005: Thermoregulation behaviour in codling moth larvae. Physiol. Entomol. 30: 54-61.

Kuhrt U., Samietz J. \& Dorn S. 2006: Thermal response in adult codling moth. Physiol. Entomol. 31: 80-88. 
LeE R.E. 1991: Principles of insect low temperature tolerance. In Lee R.E. \& Denlinger D.L. (eds): Insects at Low Temperature. Chapman \& Hall, New York, pp. 17-46.

Leslie S.B., Israeli E., Lighthart B., Crowe J.H. \& Crowe L.M. 1995: Trehalose and sucrose protect both membranes and proteins in intact bacteria during drying. Appl. Environ. Microbiol. 61: 3592-3597.

Minder I.F., Dudash A.V. \& Chesnek S.I. 1984: Seasonal changes in the resistance to cold and the content of glycogen, glycerin and reducing sugars in the body of hibernating larvae of the codling moth (Laspeyresia pomonella). Zool. Zh. 63: 1355-1362 [in Russian, English abstr.].

Miyazaki S., Kayukawa T., Chen B., Nomura M. \& Ishikawa Y. 2006: Enhancement of cold hardiness by acclimation is stage-specific in the non-diapausing pupae of onion maggot Delia antiqua (Diptera: Anthomyiidae). Eur. J. Entomol. 103: 691-694.

Moffitt H.R. \& Albano D. 1972: Effects of commercial fruit storage on stages of the codling moth. J. Econ. Entomol. 65: 770-773.

Naeemullah M., Tanaka K., Tsumuki H. \& Takeda M. 1999: Relationship of cold tolerance to developmental determination in the Indian meal moth, Plodia interpunctella (Lepidoptera: Phycitidae). Appl. Entomol. Zool. 34: 267-276.

Needham G.R., Jaworski D.C., Chen C.-P. \& Lee R.E.JR. 1996: Cold hardiness of a laboratory reared colony of lone star ticks (Acari: Ixodidae). J. Med. Entomol. 33: 706-710.

Neven L.G. 1994: Combined heat treatments and cold storage effects on mortality of fifth-instar codling moth (Lepidoptera: Tortricidae). J. Econ. Entomol. 87: 1262-1265.

Neven L.G. 1999: Cold hardiness adaptations of codling moth, Cydia pomonella. Cryobiology 38: 43-50.

Neven L.G., Ferguson H.J. \& Knight A. 2000: Sub-zero cooling synchronizes post-diapause development of codling moth, cydia pomonella. Cryo-Letters 21: 203-214.

Newcomer E.J. 1920: Winterkilling of codling moth larvae. $J$. Econ. Entomol. 13: 441-442.

NewCOMER E.J. 1936: Effect of cold storage on eggs and young larvae of codling moth. J. Econ. Entomol. 29: 1123-1125.

Nomura M. \& IshiKawa Y. 2001: Dynamic changes in cold hardiness, high temperature tolerance and trehalose content in the onion maggot, Delia antiqua (Diptera: Anthomyiidae), associated with the summer and winter diapause. Appl. Entomol. Zool. 36: 443-449.

Nordin J.H., Cui Z. \& Yin C.M. 1984: Cold-induced glycerol accumulation by Ostrinia nubilalis larvae is developmentally regulated. J. Insect Physiol. 30: 563-566.

Pellerin-Mendes C., Million L., Marchand-Arvier M., LABRUde P. \& Vigneron C. 1997: In vitro study of the protective effect of trehalose and dextran during freezing of human red blood cells in liquid nitrogen. Cryobiology 35: 173-186.

Pio C.J. \& BAUST J.G. 1988: Effects of temperature cycling on cryoprotectant profiles in the goldenrod gall fly, Eurosta solidaginis (Fitch). J. Insect Physiol. 34: 767-771.

Rajabi G., Beheshti N.D., Akrami F., Bayatassadi H., Dickler E. \& DAvoudi Z. 1978: Codling moth in Iran. An abstract of results obtained during the years 1975, 1976 and 1977. Appl. Entomol. Phytopathol. 46: 1-54.

RAUDONIS L. 2002: Effects of temperature on egg laying activity of codling moth (Cydia pomonella L.). Sodininkyste ir Darzininkyste 21: 165-173.

Richardson J.C., Jorgensen C.D. \& CRoft B.A. 1982: Embryogenesis of the codling moth, Laspeyresia pomonella: Use in validating phenology models. Ann. Entomol. Soc. Am. 75: 201-209.
Riedl H. \& CRoft B.A. 1978: The effects of photoperiodic and effective temperatures on the seasonal phenology of the codling moth (Lepidoptera: Tortricidae). Can. Entomol. 110: 455-470.

RING R.A. \& DANKS H.V. 1998: The role of trehalose in coldhardiness and desiccation. Cryo-Letters 19: 275-282.

Rojas R.R., Charlet L.D. \& Leopold R.A. 1991: Biochemistry and physiology of overwintering in the mature larva of the red sunflower seed weevil, Smicronyx fulvus Leconte (Coleoptera: Curculionidae). J. Insect Physiol. 37: 489-496.

Rojas R.R., Charlet L.D. \& Leopold R.A. 1994: Trehalose accumulation in the overwintering larva of the long-horned sunflower girdler, Dectes texanus. Cryo-Letters 15: 394-398.

Rudolph A.S. \& Goins B. 1991: The effect of hydration stress solutes on the phase behaviour of hydrated dipalmitoylphospatidylcholine. Biochim. Biophys. Acta 1066: 90-94.

SÆthre M.G. \& Hofsvang T. 2002: Effect of temperature on oviposition behavior, fecundity, and fertility in two northern european populations of the codling moth (Lepidoptera: Tortricidae). Environ. Entomol. 31: 804-815.

SAEB H. 1994: Bio-ecological investigations on codling moth in the Rasht region. J. Entomol. Soc. Iran 14: 17-18.

SAто H.A. 1964: Preliminary report on the response to temperature of the overwintering immature stage of Carpocapsa pomonella. Ann. Rept. Soc. Plant Prot. N. Japan 15: 113.

SHEL'DESHOVA G.G. 1967: Ecological factors determining distribution of the codling moth Laspeyresia pomonella L. (Lepidoptera, Tortricidae) in the northern and southern hemispheres. Entomol. Rev. 46: 349-359.

SIEGLER E.H. 1946: Susceptibility of hibernating codling moth larvae to low temperatures, and the bound water content. $J$. Agr. Res. 72: 329-340.

Sømme L. 1968: The effect of acclimation and glycerol injection on mortality and pupation in larvae of Ephestia kuehniella after exposures at low temperatures. Entomol. Exp. Appl. 11: 143-148.

Søмme L. 1982: Supercooling and winter survival in terrestrial arthropods. Comp. Biochem. Physiol. (A) 73: 519-543.

Søмme L. 1999: The physiology of cold hardiness in terrestrial arthropods. Eur. J. Entomol. 96: 1-10.

Storey J.M. \& Storey K.B. 1983: Regulation of cryoprotectant metabolism in the overwintering gall fly larvae, Eurosta solidaginis: temperature control of glycerol and sorbitol levels. $J$. Comp. Physiol. 149: 495-502.

Storey K.B. \& Storey J.M. 1988: Freeze tolerance in animals. Physiol. Rev. 68: 27-84.

Storey K.B. \& Storey J.M. 1991: Biochemistry of cryoprotectants. In Lee R.E. \& Denlinger D.L. (eds): Insects at Low Temperature. Chapman \& Hall, New York, pp. 64-93.

Tова H.H. \& Moffitт H.R. 1991: Controlled-atmosphere cold storage as a quarantine treatment for nondiapausing codling moth (Lepidoptera: Tortricidae) larvae in apples. J. Econ. Entomol. 84: 1316-1319.

TsUMUKI H. 1990: Environmental adaptations of the rice stem borer Chilo suppressalis and the blue alfalfa aphid, Acyrthosiphon kondoi to seasonal fluctuations. In Hoshi M. \& Yamashita O. (eds): Advances in Invertebrate Reproduction 5. Elsevier, Amsterdam, pp. 273-278.

Yokoyama V.Y. \& Miller G.T. 1989: Response of codling moth and oriental fruit moth (Lepidoptera, Tortricidae) immatures to low-temperature storage of stone fruits. J. Econ. Entomol. 82: 1152-1156.

Yothers M.A. \& CARLSON F.W. 1941: Orchard observations of the emergence of codling moths from two year old larvae. $J$. Econ. Entomol. 34: 109-110. 
Zachariassen K.E. 1985: Physiology of cold tolerance in insects. Physiol. Rev. 65: 799-832.

Zachariassen K.E., Kristiansen E., Pedersen S.A. \& Hammel H.T. 2004: Ice nucleation in solutions and freeze-avoiding insects-homogeneous or heterogeneous? Cryobiology 48: 309-321.
Zhou X.L., Zhu H., Zhang S.Z., Zhu F.M., Chen G.M. \& Yan L.X. 2006: Freeze-drying of human platelets: influence of intracellular trehalose and extracellular protectants. CryoLetters 27: 43-50.

Received November 1, 2006; revised and accepted February 13, 2007 